\title{
Elevated BNP caused by recombinant human interleukin-11 treatment in patients with chemotherapy-induced thrombocytopenia
}

\author{
Na-wei Liu ${ }^{1,2,3} \cdot$ Xin Huang ${ }^{4,2,3} \cdot$ Shuang Liu ${ }^{1,2,3} \cdot$ Wen-jian Liu ${ }^{1,2,3} \cdot$ Hua Wang ${ }^{1,2,3} \cdot$ Wei-da Wang ${ }^{1,2,3} \cdot$ Yue Lu ${ }^{1,2,3}$ (D)
}

Received: 28 August 2018 / Accepted: 5 March 2019/Published online: 15 March 2019

(C) The Author(s) 2019

\begin{abstract}
Thrombocytopenia is a condition characterized by abnormally low levels of thrombocytes and often induced by chemotherapy. Recombinant human interleukin-11 (rhIL-11) is a cytokine that can stimulate thrombopoiesis and is commonly used to treat thrombocytopenia. We observed the side effects of rhIL-11 in 24 leukemia patients with chemotherapy-induced thrombocytopenia. To determine the cardiovascular effects of rhIL-11, we detected changes in the patients' serum brain natriuretic peptide (BNP), blood pressure fluctuations, weight change, and whether edema or heart failure occurred in leukemia patients after chemotherapy. The results showed that BNP was significantly elevated after using rhIL-11 $(P<0.05)$ but regressed after $2-$ 4 days. Furthermore, nine patients had edema and experienced weight gain, and four experienced acute left heart failure. In addition, the average blood pressure was $119 / 75 \mathrm{mmHg}$ (range $139 / 86 \mathrm{mmHg}$ to $99 / 64 \mathrm{mmHg}$ ) before rhIL-11 administration and $127 / 79 \mathrm{mmHg}$ (range $146 / 89 \mathrm{mmHg}$ to $108 / 69 \mathrm{mmHg}$ ) after rhIL-11 use. In conclusion, although rhIL-11 is useful for treating chemotherapy-induced thrombocytopenia, it is important to monitor the patients' clinical status and re-examine BNP levels frequently during the use of rhIL-11. Furthermore, senile patients should be given special attention. However, the appropriate timing to begin and discontinue rhIL-11 treatment needs further investigation.
\end{abstract}

Keywords Thrombocytopenia · Chemotherapy · Recombinant human interleukin-11 (rhIL-11) · Brain natriuretic peptide (BNP) · Heart failure

\section{Introduction}

Acute leukemia $(\mathrm{AL})$ is a malignant clonal hematopoietic disorder that originates from genetic alterations in healthy

Na-wei Liu, Xin Huang, and Shuang Liu have contributed equally to this work.

Yue Lu

lvyuesysucc@163.com

Na-wei Liu

liunw@sysucc.org.cn

Xin Huang

huangxin1@sysucc.org.cn

Shuang Liu

liushuang@ sysucc.org.cn

Wen-jian Liu

doclwjian@163.com

Hua Wang

wanghua@sysucc.org.cn hematopoietic stem cells. These affected cells multiply vigorously in the bone marrow and other hematopoietic tissues and can further infiltrate nonhematopoietic tissues and organs while suppressing normal hematopoietic

Wei-da Wang

wangwd@sysucc.org.cn

1 Department of Hematologic Oncology, Sun Yat-sen University Cancer Center, Guangzhou, China

2 Center State Key Laboratory of Oncology in South China, Guangzhou, China

3 Collaborative Innovation Center for Cancer Medicine, 651 Dongfeng East Road, Guangzhou 510060, People's Republic of China

4 Department of Hepatobiliary Oncology, Sun Yat-sen University Cancer Center, Guangzhou, China 
processes. The clinical manifestations of AL include various degrees of anemia, bleeding, infection, hepatosplenomegaly, lymphadenectasis, and bone pain. $\mathrm{AL}$ is a highly malignant systemic disease, and the preferred treatment is systemic chemotherapy, which can cause severe bone marrow suppression. Platelet reduction is one of the main manifestations of bone marrow suppression in patients. Thrombocytopenia can result in mucocutaneous hemorrhage and may even cause bleeding in vital organs that is life-threatening to patients.

The human IL-11 gene is located on chromosome 19. The protein encoded by this gene is a multipurpose cytokine that was first detected in bone marrow-derived stromal cells in 1990. IL-11 is a member of the IL-6-type cytokine family, which is distinguished by their interaction with the common coreceptor gp130 and plays an important role during the hematopoiesis process. Furthermore, the IL-6-type cytokine family has a synergistic effect on a variety of cytokines, with one of the most notable effects being the stimulation of megakaryocyte maturation resulting in increased platelet production [1]. Recombinant human interleukin-11 (rhIL-11) is currently undergoing a series of clinical trials and is used as a preferred drug to treat chemotherapy-induced thrombocytopenia [2-4].

Brain natriuretic peptide (BNP) is a natural hormone secreted by cardiomyocytes expressed in the ventricles and brain tissue. BNP secreted from cardiomyocytes is present as a precursor of 108 amino acids. When cardiomyocytes are stimulated, BNP is cleaved into an inactive linear polypeptide comprising 76 amino acids and an active cyclic peptide consisting of 32 amino acids. Upon stimulation of an activating enzyme, the inactive linear polypeptide and the active cyclic peptide are released into the blood circulation, respectively known as NT-proBNP and BNP [5]. The active protein's physiological effects include natriuresis, diuresis, vasorelaxation, inhibition of renin and aldosterone secretion, and contributions to cardiovascular homeostasis. High levels of BNP in the bloodstream suggest acute heart failure. According to data from the UK, a cutoff in BNP concentration of $100 \mathrm{pg} / \mathrm{ml}$ has a sensitivity of approximately $100 \%$, a negative predictive value of approximately $100 \%$, a specificity of $90 \%$, and a positive predictive value of $78 \%$ for cardiac events [6].

In clinical practice, we observed that a certain number of patients presented with various degrees of edema and occasional chest pain after rhIL-11 injection. We suspect that this may be related to the effects of rhIL-11 on the circulatory system. Therefore, we designed this study to explore the correlation between rhIL-11 administration and BNP concentration in leukemia patients after receiving chemotherapy. The possible underlying mechanism of the effect of rhIL-11 on the circulatory system is also discussed.

\section{Methods}

\section{Patients}

Twenty-four adult patients diagnosed with leukemia who received chemotherapy between October 2016 and May 2017 at the Department of Hematologic Oncology, Cancer Center, Sun Yat-Sen University were enrolled. All patients had a confirmed diagnosis of leukemia according to the FrenchAmerican-British (FAB) classification system based on clinical features, bone marrow cytology, flow cytometric evaluation, and cytogenetic detection. All patients had a Karnofsky performance status (KPS) score $>70$. Patients with basic heart disease were excluded by ultrasound, electrocardiogram, and blood biochemistry.

\section{Treatment}

Nine patients were diagnosed with acute lymphoblastic leukemia (ALL), seven of whom were treated with the MRC UKALLXII/ECOG E2993 protocol (from a joint international study initiated by the Medical Research Council in the UK and the Eastern Cooperative Oncology Group in the US in 1993) [22], and the other two received VDLP regimens. The remaining 15 patients with acute myeloid leukemia were treated with AML-201 [23].

\section{Dosing method}

The patients underwent a bone marrow suppression period after chemotherapy. When their platelet count was $\leq 50 \times$ $109 / \mathrm{L}$, the patients were given a subcutaneous injection of rhIL-11 at $3 \mathrm{mg}$ once a day for no more than 14 days until the platelet count was $\geq 20 \times 109 / \mathrm{L}$.

\section{Serum BNP measurement}

We measured the serum BNP concentration 2-3 days before rhIL-11 treatment. During IL-11 administration, the patients' BNP levels were re-examined twice a week. Finally, we measured the BNP concentration once again 2-5 days after withdrawal of rhIL-11 medication.

\section{Cell culture}

H9C2 rat cardiomyocytes were cultured in $10 \% \mathrm{FBS}$ at $37^{\circ} \mathrm{C}$ with $5 \% \mathrm{CO}_{2}$, and the medium was changed every 2-3 days.

\section{Real-time quantitative reverse transcription polymerase chain reaction}

The BNP mRNA levels in cardiomyocytes were detected by real-time quantitative reverse transcription polymerase chain 
reaction (RT-PCR) according to the manufacturer's instructions. The primer sequences used for RT-PCR were as follows: mouse BNP, forward 5'-TCCTAGCCAGTCTC CAGAGCAA-3', reverse 5'-GGTCCTTCAAGAGC TGTCTCTG-3'; mouse GAPDH, forward 5'-CATC ACTGCCACCCAGAAGACTG-3', reverse 5'-ATGC CAGTGAGCTTCCCGTTCAG-3'; rat BNP:, forward 5'AGCTGCTGGAGCTGATAAGAG-3', reverse 5'-CGCC GATCCGGTCTATCTTC-3'; and rat GAPDH, forward 5'CATCACTGCCACCCAGAAGACTG-3', reverse 5'-ATGC CAGTGAGCTTCCCGTTCAG-3'. Real-time quantitative RT-PCR was performed for each sample in duplicate with GAPDH as a housekeeping gene. The comparative cycle threshold $(\mathrm{Ct})$ method was used to determine the relative expression of BNP. Each sample was tested in triplicate.

\section{Statistical analysis}

All statistical analyses were performed with SPSS software (version 13.0, SPSS Inc., Chicago, IL, USA). To make comparisons, the BNP index, blood pressure, and weight change before and after the use of rhIL-11 were estimated using a $t$ test. The results of the comparative tests were considered significantly different if the two-sided $P$ value was less than 0.05 .

Data availability Literature collection was performed through PubMed. All statistical analyses were performed using SPSS 19.0 or Graphpad Prism6.0. Data are stored in the corresponding author of this article and are available upon request.

\section{Results}

\section{Patient characteristics}

The clinical characteristics (including age and gender) of the 24 patients observed in this study are listed in Table 1 . The ratio of males to females was $1.67: 1$, with a median age of 36.3 years (range, 19-66 years). All patients experienced grade IV myelosuppression after chemotherapy, and none of the patients had a history of heart disease.

\section{Variation in serum BNP before and after rhIL-11 administration}

The mean concentration of serum BNP for all patients was $21.85 \mathrm{pg} / \mathrm{mL}$ (range, $0-99.05 \mathrm{pg} / \mathrm{mL}$ ), with a median of $18.96 \mathrm{pg} / \mathrm{mL}$ before rhIL-11 treatment. During rhIL-11 treatment, the serum BNP of all the patients was surprisingly increased to an average concentration of $215.00 \mathrm{pg} / \mathrm{mL}$, which was significantly higher than that before treatment $(P<0.001$, Fig. 1). The BNP levels in 19 patients exceeded $100 \mathrm{pg} / \mathrm{mL}$, which is regarded as the cutoff to predict heart failure. We tested BNP once again 2-5 days after stopping rhIL-11 treatment, and the mean serum BNP concentration returned to $69.78 \mathrm{pg} / \mathrm{mL}(P<0.001$, Fig. 1$)$.

\section{Relationship between serum BNP levels and clinical features}

The concentration of serum BNP has been reported to increase when patients have sodium retention. The patients in this situation often presented leg edema and weight gain [7,8]. Furthermore, edema is an important subclinical symptom of heart failure. In our study, nine patients had edema and weight gain, and four of them developed acute left heart failure. Additionally, two patients had paroxysmal atrial fibrillation. Heart failure in these patients was reversible and improved with careful medication regimens. It should be mentioned that there is an inseparable relationship between BNP and blood pressure [9-12]. The patients' blood pressure was $119 \pm 20$ $/ 75 \pm 11 \mathrm{mmHg}$ and $127 \pm 19 / 79 \pm 10 \mathrm{mmHg}$ before and after using rhIL-11, respectively ( $P<0.005$, Fig. 2$)$.

\section{Change in BNP mRNA expression in the H9C2 cardiomyocyte cell line after rhIL-11 stimulation}

We used different concentrations of rhIL-11 $(0 / 20 / 40 \mathrm{ng} / \mathrm{ml})$ to stimulate $\mathrm{H} 9 \mathrm{C} 2$ cardiomyocytes and detected the mRNA expression of BNP with quantitative real-time RT-PCR. We found that the mRNA expression of BNP in cardiomyocytes was significantly increased, showing a positive correlation with the stimulation time and drug concentration (Fig. 2).

\section{Discussion}

Several published studies have investigated the cardiotoxicity of rhIL-11, and most of the observed pathologies were reversible arrhythmia [13-16]. However, the concomitant elevation of BNP and incidence of heart failure are seldom mentioned. Based on our clinical observations and monitoring, it was no coincidence between elevated BNP levels and increases in their associated clinical symptoms caused by rhIL- 11 . During rhIL-11 administration, the serum BNP and blood pressure of all the patients were increased. Nine patients had edema and weight gain, and four of them presented acute left heart failure.

To further validate our results, we conducted a series of in vitro cell-based experiments. In cardiomyocytes stimulate with rhIL-11, the mRNA levels of BNP were increased, which is consistent with our clinical observations. Studies have shown that cytokines of the IL-6 family induce cardiomyocyte hypertrophy [17-20] resulting in increased ANP and BNP expression and activation of the p42/p44-MAPK and PI3K signaling pathways may be related [21]. Since IL-11 is a 
Table 1 Patients characteristics

\begin{tabular}{|c|c|c|c|c|c|c|c|c|c|c|c|c|}
\hline $\begin{array}{l}\text { Patients } \\
\text { no. }\end{array}$ & $\begin{array}{l}\text { Age } \\
\text { years }\end{array}$ & Gender & Diagnosis & Treatment & $\begin{array}{l}\text { Initial } \\
\text { serum } \\
\text { BNP } \\
\text { level }\end{array}$ & $\begin{array}{l}\text { Mean serum } \\
\text { BNP level } \\
\text { during } \\
\text { medication }\end{array}$ & $\begin{array}{l}\text { Serum } \\
\text { BNP level } \\
\text { after } \\
\text { medication }\end{array}$ & $\begin{array}{l}\text { Clinical } \\
\text { manifestation } \\
\text { of } \mathrm{HF}\end{array}$ & $\begin{array}{l}\text { Initial } \\
\text { weight }\end{array}$ & $\begin{array}{l}\text { Weight } \\
\text { during } \\
\text { medication }\end{array}$ & $\begin{array}{l}\text { Initial } \\
\mathrm{BP}\end{array}$ & $\begin{array}{l}\text { BP during } \\
\text { medication }\end{array}$ \\
\hline 1 & 22 & Female & AML & AML201 & 0 & 109.94 & 38.11 & No & 31 & 32 & $128 / 86$ & $135 / 89$ \\
\hline 2 & 34 & Male & ALL & VDLP & 21.08 & 79.28 & 26.23 & No & 58 & 57.5 & $128 / 71$ & $134 / 80$ \\
\hline 3 & 23 & Male & AML & AML201 & 0 & 35.91 & 10.5 & No & 65 & 65 & $120 / 71$ & $128 / 75$ \\
\hline 4 & 29 & Female & AML & AML201 & 5.35 & 131.10 & 41.64 & No & 47 & 47 & $105 / 65$ & $110 / 70$ \\
\hline 5 & 36 & Female & AML & AML201 & 0 & 207.76 & 12.04 & No & 48 & 48.5 & $103 / 75$ & $110 / 78$ \\
\hline 6 & 49 & Female & AML & AML201 & 20.33 & 63.81 & 7.74 & No & 57 & 56.5 & $113 / 74$ & $121 / 82$ \\
\hline 7 & 22 & Female & ALL & E2993 & 21.46 & 73.07 & 31.4 & No & 46 & 46.8 & $109 / 73$ & $115 / 78$ \\
\hline 8 & 35 & Female & AML & AML201 & 0 & 129.23 & 19.61 & No & 45.5 & 45 & $133 / 80$ & $135 / 81$ \\
\hline 9 & 58 & Male & AML & AML201 & 99.05 & 359.28 & 168.6 & Yes & 69 & 75 & $140 / 80$ & $146 / 85$ \\
\hline 10 & 53 & Female & CML & AML201 & 17.58 & 33.37 & 37.27 & No & 40 & 40 & $130 / 81$ & $136 / 85$ \\
\hline 11 & 59 & Female & AML & AML201 & 24.5 & 173.98 & 148.57 & No & 53 & 52 & $117 / 67$ & $120 / 69$ \\
\hline 12 & 30 & Female & ALL & VDLP & 22.68 & 105.66 & 60.59 & No & 49 & 48.5 & $105 / 66$ & $109 / 70$ \\
\hline 13 & 20 & Male & ALL & E2993 & 4.93 & 44.29 & 35.89 & No & 74 & 74 & $118 / 72$ & $124 / 75$ \\
\hline 14 & 19 & Male & ALL & E2993 & 55.21 & 84.77 & 30.12 & No & 80 & 80 & $134 / 81$ & $138 / 89$ \\
\hline 15 & 34 & Female & AML & AML201 & 5.26 & 109.91 & 109.05 & No & 53 & 54 & $109 / 71$ & $116 / 79$ \\
\hline 16 & 30 & Male & ALL & E2993 & 8.72 & 19.08 & 9.56 & No & 71 & 70 & $122 / 75$ & $128 / 78$ \\
\hline 17 & 32 & Female & $\begin{array}{l}\text { AML } \\
\text { relapse }\end{array}$ & $\begin{array}{l}\text { Cladribine+ } \\
\text { Aclarubicin }\end{array}$ & 2.52 & 95.91 & 46.79 & No & 39 & 39 & $112 / 69$ & $120 / 74$ \\
\hline 18 & 30 & Male & ALL & E2993 & 27.4 & 35.68 & 33.33 & No & 75 & 74.5 & $135 / 79$ & $138 / 84$ \\
\hline 19 & 53 & Female & AML & $\begin{array}{l}\text { Cladribine+ } \\
\text { Aclarubicin+ } \\
\text { Cytarabine }\end{array}$ & 35.28 & 502.47 & 78.61 & Yes & 70 & 74 & $134 / 79$ & $139 / 85$ \\
\hline 20 & 40 & Female & AML & AML201 & 2 & 127.12 & 6.37 & No & 50 & 49.5 & $113 / 77$ & $119 / 84$ \\
\hline 21 & 25 & Female & AML & AML201 & 77.29 & 213.42 & 103.4 & No & 44 & 45 & $99 / 63$ & $108 / 72$ \\
\hline 22 & 42 & Male & AML & AML201 & 27.26 & 181.29 & 68.78 & No & 58 & 58 & $99 / 66$ & $110 / 74$ \\
\hline 23 & 29 & Female & ALL & E2993 & 4.11 & 899.71 & 84.36 & Yes & 55 & 57 & $128 / 82$ & $136 / 88$ \\
\hline 24 & 66 & Male & ALL & E2993 & 42.4 & 1343.97 & 466.14 & Yes & 64 & 67 & $133 / 79$ & $137 / 88$ \\
\hline
\end{tabular}

member of the IL- 6 family, we infer that IL-11 can also cause elevated BNP via the cardiac hypertrophy pathway.

The variation of BNP in patients'serum

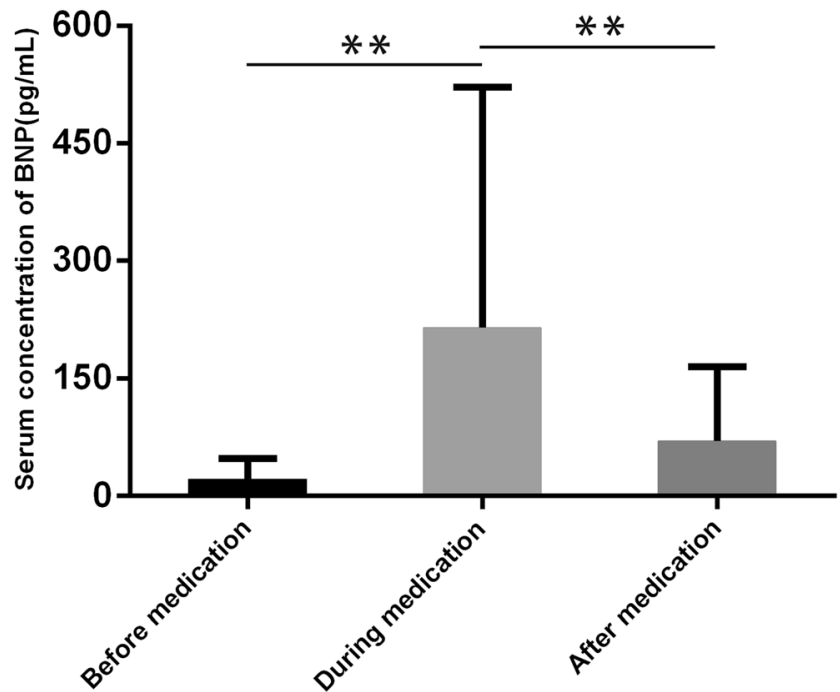

Fig. 1 The mean concentration of serum BNP in leukemia patients was $215.00 \mathrm{pg} / \mathrm{mL}$ during rhIL-11 treatment, which was significantly higher than that before treatment $(21.85 \mathrm{pg} / \mathrm{mL})$. At $2-5$ days after stopping rhIL-11 administration, the mean concentration of serum BNP returned to $69.78 \mathrm{pg} / \mathrm{mL}$ (mean $\pm \mathrm{SD} ; P<0.001)$
The use of adjuvant therapy is critical for leukemia patients undergoing chemotherapy. rhIL-11 is widely used to treat grade III or grade IV thrombocytopenia (i.e., platelets $\leq 50 \times$ $109 / \mathrm{L}$ ). As a result, the number of thrombocytes is indeed increased, and the risk of bleeding is reduced. However, the side effects of rhIL-11 cannot be ignored. Through our clinical observations and experiments, we conclude that the use of rhIL-11 can either directly or indirectly induce cardiotoxicity.

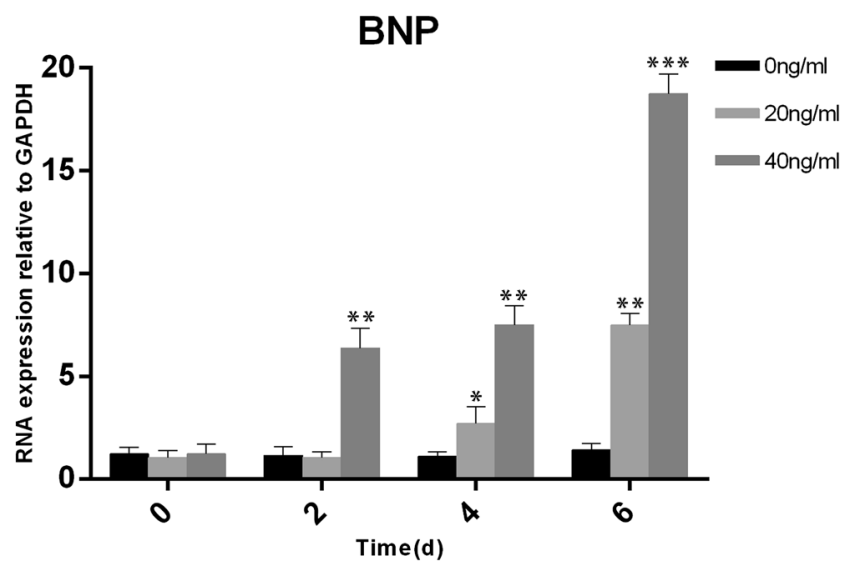

Fig. $2 \mathrm{H} 9 \mathrm{C} 2$ cells were stimulated with rhIL-11 at a concentration of $0 / 20 / 40 \mathrm{ng} / \mathrm{ml}$. BNP expression was determined by qRT-PCR at 48,96 , and $144 \mathrm{~h}$ after stimulation (mean $\pm \mathrm{SD}$ ). $* P<0.05$, $* * P<0.01$, $* * * P<0.001 ;$ Student's $t$ test 
BNP is a good marker for cardiotoxicity, and we recommend routine detection of BNP when administering rhIL-11. Daily measurement of blood pressure and body weight is also suggested. We do not advise the use of rhIL-11 in any patients with conditions that may cause or exacerbate existing heart failure, such as underlying heart disease, pulmonary infection, or other situations. Caution should be taken when considering rhIL-11 use in older and more frail patients.

The main limitation of our experiment is that the sample size of this study is small, and our task in the next stage is to expand the cohort to further confirm the results of this study. Additionally, more cell experiments can verify our conclusions. For example, secreted BNP protein levels can be detected by ELISA, and pathway proteins can be detected by Western blot. We will expound our observations in the follow-up study and explore the mechanism of rhIL-11-induced cardiotoxicity in greater depth.

Acknowledgements The authors would like to thank the staff members of the Department of Hematologic Oncology, Cancer Center, Sun Yat-sen University, for their valuable suggestions and assistance.

Author's contributions NWL, XH, LS, and LY designed the experiments; NWL, XH, LS, WJL, WH, and WDW conducted experiments; NWL, XH, LS, and LY contributed vital new reagents or analytical tools, analyzed data and wrote the manuscript. All authors read and approved the final manuscript.

Funding Our work was supported by the following funds: National Natural Science Foundation of China (Contract/Grant Number 81272620) and Science and Technology Projects of Guangdong Province (Contract/Grant Number 2016A020215086).

\section{Compliance with ethical standards}

Ethical approval and consent to participate This research followed the protocols approved by the Institutional Review Board and the ethics committees of Sun Yat-sen University Cancer Center.

\section{Consent for publication Not applicable.}

Competing interests The authors declare that they have no conflict of interest.

Open Access This article is distributed under the terms of the Creative Commons Attribution 4.0 International License (http:// creativecommons.org/licenses/by/4.0/), which permits unrestricted use, distribution, and reproduction in any medium, provided you give appropriate credit to the original author(s) and the source, provide a link to the Creative Commons license, and indicate if changes were made.

\section{References}

1. Berry C, Kingsmore D, Gibson S, Hole D, Morton JJ, Byrne D, Dargie HJ (2006) Predictive value of plasma brain natriuretic peptide for cardiac outcome after vascular surgery. Heart 92(3):401-402

2. Cui XL, Wang L, Gao J, Qin P, Shi Y, Peng J, Hou M (2005) The efficacy and mechanism of Rhil-11 in the management of chemotherapy-induced thrombocytopenia in acute leukemia. Zhonghua Xue Ye Xue Za Zhi 26(6):345-347
3. Fredj S, Bescond J, Louault C, Delwail A, Lecron JC, Potreau D (2005) Role of interleukin-6 in cardiomyocyte/cardiac fibroblast interactions during myocyte hypertrophy and fibroblast proliferation. J Cell Physiol 204(2):428-436

4. Goldstone AH, Richards SM, Lazarus HM, Tallman MS, Buck G, Fielding AK, Burnett AK, Chopra R, Wiernik PH, Foroni L, Paietta E, Litzow MR, Marks DI, Durrant J, McMillan A, Franklin IM, Luger S, Ciobanu N, Rowe JM (2008) In adults with standard-risk acute lymphoblastic leukemia, the greatest benefit is achieved from a matched sibling allogeneic transplantation in first complete remission, and an autologous transplantation is less effective than conventional consolidation/maintenance chemotherapy in all patients: final results of the International All Trial (Mrc Ukall Xii/Ecog E2993). Blood 111(4):1827-1833

5. Gordon MS (1996) Thrombopoietic activity of recombinant human interleukin 11 in cancer patients receiving chemotherapy. Cancer Chemother Pharmacol 38(SUPPL):S96-S98

6. Hirayama A, Torimoto K, Yamada A, Tanaka N, Fujimoto K, Yoshida K, Hirao Y (2011) Relationship between nocturnal urine volume, leg edema, and urinary antidiuretic hormone in older men. Urology 77(6):1426-1431

7. Kaye JA (1996) Clinical development of recombinant human interleukin-11 to treat chemotherapy-induced thrombocytopenia. Curr Opin Hematol 3(3):209-215

8. Kou HJ, Wang X, Gao DF, Dong X, Wei J, Ma R (2016) Relationships of blood pressure circadian rhythm and brain natriuretic peptide with left ventricular hypertrophy in the patients with primary hypertension. Zhongguo Yi Xue Ke Xue Yuan Xue Bao 38(5):514-521

9. Miyawaki S, Ohtake S, Fujisawa S, Kiyoi H, Shinagawa K, Usui N, Sakura T, Miyamura K, Nakaseko C, Miyazaki Y, Fujieda A, Nagai T, Yamane T, Taniwaki M, Takahashi M, Yagasaki F, Kimura Y, Asou N, Sakamaki H, Handa H, Honda S, Ohnishi K, Naoe T, Ohno R (2011) A randomized comparison of 4 courses of standard-dose multiagent chemotherapy versus 3 courses of highdose cytarabine alone in postremission therapy for acute myeloid leukemia in adults: the Jalsg Aml201 Study. Blood 117(8):23662372

10. Paul SR, Bennett F, Calvetti JA, Kelleher K, Wood CR, O'Hara RM Jr, Leary AC, Sibley B, Clark SC, Williams DA et al (1990) Molecular cloning of a Cdna encoding interleukin 11, a stromal cell-derived lymphopoietic and hematopoietic cytokine. Proc Natl Acad Sci U S A 87(19):7512-7516

11. Pennica D, King KL, Shaw KJ, Luis E, Rullamas J, Luoh SM, Darbonne WC, Knutzon DS, Yen R, Chien KR et al (1995) Expression cloning of cardiotrophin 1, a cytokine that induces cardiac myocyte hypertrophy. Proc Natl Acad Sci U S A 92(4):11421146

12. Rowe JM, Buck G, Burnett AK, Chopra R, Wiernik PH, Richards SM, Lazarus HM, Franklin IM, Litzow MR, Ciobanu N, Prentice HG, Durrant J, Tallman MS, Goldstone AH (2005) Induction therapy for adults with acute lymphoblastic leukemia: results of more than 1500 patients from the International All Trial: Mrc Ukall xii/ Ecog E2993. Blood 106(12):3760-3767

13. Sartiani L, De Paoli P, Lonardo G, Pino R, Conti AA, Cerbai E, Pelleg A, Belardinelli L, Mugelli A (2002) Does recombinant human interleukin-11 exert direct electrophysiologic effects on single human atrial myocytes? J Cardiovasc Pharmacol 39(3):425-434

14. Schellenberger U, O'Rear J, Guzzetta A, Jue RA, Protter AA, Pollitt NS (2006) The precursor to B-type natriuretic peptide is an Olinked glycoprotein. Arch Biochem Biophys 451(2):160-166

15. Shibasaki S, Hoshide S, Eguchi K, Ishikawa J, Kario K (2015) Increase trend in home blood pressure on a single occasion is associated with B-type natriuretic peptide and the estimated glomerular filtration rate. Am J Hypertens 28(9):1098-1105 
16. Shimizu M, Ishikawa J, Yano Y, Hoshide S, Eguchi K, Ishikawa S, Shimada K, Kario K (2012) Association between asleep blood pressure and brain natriuretic peptide during antihypertensive treatment: the Japan Morning Surge-Target Organ Protection (J-Top) study. J Hypertens 30(5):1015-1021

17. Smith JW 2nd. (2000) Tolerability and side-effect profile of Rhil11. Oncology (Williston Park) 14(9 Suppl 8):41-47

18. Tepler I, Elias L, Ii Smith JW, Hussein M, Rosen G, Chang AYC, Moore JO, Gordon MS, Kuca B, Beach KJ, Loewy JW, Garnick MB, Kaye JA (1996) A randomized placebo-controlled trial of recombinant human interleukin-11 in cancer patients with severe thrombocytopenia due to chemotherapy. Blood 87(9):3607-3614

19. Woods DR, Mellor A, Begley J, Stacey M, O'Hara J, Hawkins A, Yarker J, Foxen S, Smith C, Boos C (2013) Brain natriuretic peptide and Nt-Probnp levels reflect pulmonary artery systolic pressure in trekkers at high altitude. Physiol Res 62(6):597-603

20. Xu J, Ren JF, Mugelli A, Belardinelli L, Keith JC Jr, Pelleg A (2002) Age-dependent atrial remodeling induced by recombinant human Interleukin-11: implications for atrial flutter/fibrillation. J Cardiovasc Pharmacol 39(3):435-440

21. Yamamoto A, Mankumo M, Kawaguchi A, Nishizawa H, Toyoshima H, Kangawa K (2001) Leg edema, St-T abnormalities, and high Bnp values are important signs of heart failure in the elderly. Arch Gerontol Geriatr 33(1):37-52
22. Goldstone AH, Richards SM, Lazarus HM, Tallman MS, Buck G, Fielding AK, Burnett AK, Chopra R, Wiernik PH, Foroni L, Paietta E, Litzow MR, Marks DI, Durrant J, McMillan A, Franklin IM, Luger S, Ciobanu N, Rowe JM (2008) In adults with standard-risk acute lymphoblastic leukemia, the greatest benefit is achieved from a matched sibling allogeneic transplantation in first complete remission, and an autologous transplantation is less effective than conventional consolidation/maintenance chemotherapy in all patients: final results of the International ALL Trial (MRC UKALL XII/ ECOG E2993). Blood 111:1827-1833

23. Miyawaki S, Ohtake S, Fujisawa S, Kiyoi H, Shinagawa K, Usui N, Sakura T, Miyamura K, Nakaseko C, Miyazaki Y, Fujieda A, Nagai T, Yamane T, Taniwaki M, Takahashi M, Yagasaki F, Kimura Y, Asou N, Sakamaki H, Handa H, Honda S, Ohnishi K, Naoe T, Ohno R (2011) A randomized comparison of 4 courses of standard-dose multiagent chemotherapy versus 3 courses of highdose cytarabine alone in postremission therapy for acute myeloid leukemia in adults: the JALSG AML201 study. Blood 117:23662372

Publisher's note Springer Nature remains neutral with regard to jurisdictional claims in published maps and institutional affiliations. 